Supplement of Biogeosciences, 16, 3605-3619, 2019 https://doi.org/10.5194/bg-16-3605-2019-supplement (C) Author(s) 2019. This work is distributed under the Creative Commons Attribution 4.0 License.

(c) (1)

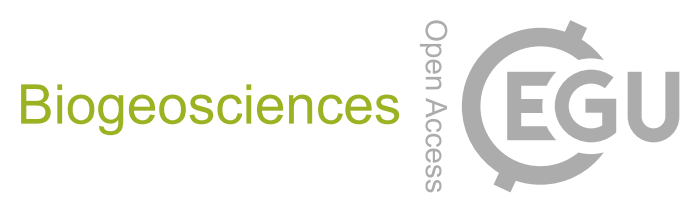

Supplement of

\title{
Past aridity's effect on carbon mineralization potentials in grassland soils
}

Zhenjiao Cao et al.

Correspondence to: Xiaojuan Feng (xfeng@ibcas.ac.cn)

The copyright of individual parts of the supplement might differ from the CC BY 4.0 License. 


\section{Supplementary Materials and Methods}

\section{S1.1 Analysis of phospholipid fatty acids (PLFAs)}

Briefly, a modified Bligh-Dyer extraction (Bligh and Dyer, 1959) was performed on $\sim 5 \mathrm{~g}$ of freeze-dried soils using mixtures of methanol, dichloromethane and citrate buffer (30 mL; 1:2:0.8, v:v:v). Total lipid extract was fractionated into neutral lipids, glycolipids, and polar lipids with $10 \mathrm{ml}$ chloroform, $20 \mathrm{~mL}$ acetone, and $10 \mathrm{~mL}$ methanol through a silica gel column, respectively. The polar lipid fraction containing phospholipids was evaporated to dryness under nitrogen gas and converted into fatty acid methyl esters (FAMEs) by a mild alkaline methanolysis reaction (Guckert et al., 1985). FAMEs were recovered with a mixture of hexane and dichloromethane $(4: 1, \mathrm{v} / \mathrm{v})$. Solvents were evaporated under nitrogen and the extracts were re-dissolved in $200 \mu \mathrm{L}$ hexane with cholestane added as an internal standard. FAMEs were analyzed on a Trace 1310 gas chromatograph (GC) coupled to an ISQ mass spectrometer (MS; Thermo Fisher Scientific, USA) using a DB-5MS column $(30 \mathrm{~m} \times 0.25 \mathrm{~mm}$ i.d., film thickness, $0.25 \mu \mathrm{m})$ for separation. The GC oven temperature increased from $100^{\circ} \mathrm{C}$ (initial hold time $5 \mathrm{~min}$ ) to $240^{\circ} \mathrm{C}$ at a rate of $4^{\circ} \mathrm{C} \mathrm{min}{ }^{-1}$ with helium as the carrier gas $\left(1.2 \mathrm{~mL} \mathrm{~min}^{-1}\right)$. The mass spectrometer was operated in an EI mode with ionization energy of $70 \mathrm{eV}$ and scanned from 50 to 650 daltons. Individual PLFAs were identified by comparison of mass spectra and retention times with authentic standards. Quantification was achieved by comparison with the internal standard in the total ion current (TIC).

Fatty acids are designated according to the standard PLFA nomenclature (Guckert et al., 1985). Because PLFA 18:3 (a commonly used indicator of plant lipids; Harwood and Russell, 1984) is not observed in our soils, contributions of plant-derived PLFAs are considered to be negligible. Gram-positive (G+) bacteria are represented by PLFAs $i 15: 0, a 15: 0, i 16: 0, i 17: 0$ and $a 17: 0$ while Gram-negative (G-) bacteria are represented

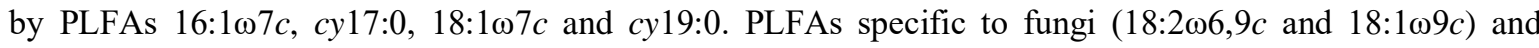
actinomycetes (10Me16:0, 10Me17:0, 10Me18:0) are also summarized (Harwood and Russell, 1984). Microbial biomass is represented by total PLFAs (Feng and Simpson, 2009), including all identified PLFAs $\left(\mathrm{C}_{14}-\mathrm{C}_{19}, 20: 0\right.$; Table S6).

The ${ }^{13} \mathrm{C}$ isotopic composition of individual FAMEs was analyzed on a Thermo Trace GC Ultra coupled to a stable isotope ratio mass spectrometry (Thermo MAT 253, Germany) via a combustion interface (GC-C-IRMS) using similar conditions as the GC/MS analysis. The $\delta^{13} \mathrm{C}$ values of PLFAs were corrected for the methyl carbon added to FAMEs by methanolysis using a mass balance equation (Denef et al., 2009):

$$
\delta^{13} C_{P L F A}=\frac{\left(N_{P L F A}+1\right) \times \delta^{13} C_{F A M E}-\delta^{13} C_{M e O H}}{N_{P L F A}}
$$

where $\delta^{13} \mathrm{C}$ is the isotope ratio for PLFAs, FAMEs or methanol $(\mathrm{MeOH})$ used in methanolysis $(-21.65 \%$ o indicated by the subscripts, $\mathrm{N}_{\text {PLFA }}$ is the number of carbon atoms of individual PLFAs. For each soil sample, the $\delta^{13} \mathrm{C}$ of total PLFAs was estimated by the abundance-weighted average of 10 most abundant PLFAs that on average represented $\sim 42 \%$ of total PLFAs in all samples, including $\mathrm{G}+(i 15: 0, a 15: 0, i 16: 0, i 17: 0$ and $a 17: 0), \mathrm{G}-(16: 1 \omega 7 c$ and $c y 17: 0)$ and non-specific PLFAs (16:0, 18:0 and 20:0). The proportion of 
litter-derived carbon in PLFAs was calculated as below (Fry, 2006):

$$
\text { PLFA }-C_{\text {litter }}=\frac{\delta^{13} C_{P L F A}-\delta^{13} c_{\text {control }}}{\delta^{13} c_{\text {litter }}-\delta^{13} c_{\text {control }}} \times 100 \%
$$

where $\delta^{13} \mathrm{C}_{\text {PLFA }}, \delta^{13} \mathrm{C}_{\text {control }}$ and $\delta^{13} \mathrm{C}_{\text {litter }}$ are the isotope value of total PLFAs in the litter-amended and control soils and of bulk litter, respectively.

\section{S1.2 Assay of extracellular enzyme activity}

Briefly, $1 \mathrm{~g}$ of fresh soil was added into $91 \mathrm{ml}$ MilliQ water and homogenized with a magnetic stirrer for 3 $\min$. For the hydrolases, the resulting suspension $(200 \mu \mathrm{l})$ was dispensed into 96 -well microplates with $50 \mu \mathrm{l}$ of 4-methylumbelliferone for $\alpha$-glucosidase, $\beta$-glucosidase and alkaline phosphatase or 4-methylumbelliferone for leucine-aminopeptidase in $\mathrm{pH}$ buffers. The microplates were incubated in the dark at $25^{\circ} \mathrm{C}$ for $4 \mathrm{~h}$. For phenol oxidase analysis, $50 \mu \mathrm{l}$ of L-3,4-dihydroxyphenylalanine $(5 \mathrm{mM})$ in tris buffer solutions ( $\mathrm{pH}$ of 8.2) were added to each sample well and incubated in the dark at $25^{\circ} \mathrm{C}$ for $3 \mathrm{~h}$. Eight replicate wells were used per sample per assay. Potential enzyme activity was quantified using Multi-Mode Microplate Reader (synergy Mx, BioTek Instruments Inc., USA). Fluorescence (tested for hydrolases) was measured with excitation at $365 \mathrm{~nm}$ and emission at $450 \mathrm{~nm}$, while absorbance (for phenol oxidase) was measured at $450 \mathrm{~nm}$.

\section{S1.3 Structural equation modelling (SEM)}

Environmental variables were selected based on the results of bivariate correlations and hypothetical pathways and grouped into the following categories: past aridity (represented by aridity index of the sampling sites), soil $\mathrm{pH}$, soil minerals (including $\mathrm{Fe}_{\mathrm{d}}, \mathrm{Al}_{\mathrm{d}}$ and clay content), SOM properties (including $\mathrm{SOC}$, SOC/N ratio and WEOC content), microbial biomass (total PLFAs), hydrolases ( $\alpha$-glucosidase, $\beta$-glucosidase, alkaline phosphatase and leucine-aminopeptidase activities) and phenol oxidase activity. As microbial CUE' was correlated with mineralization potentials or aridity index, it was hence not included in the model. For the category encompassing more than one variable, a principal component analysis (PCA) was performed and the first principal component (PC 1) was used to represent the corresponding category of variables to avoid self-correlation. The Kaiser-Meyer-Olkin (KMO) test and Bartlett test of sphericity (BS) were used to assess the performance of PCA (Table S5).

Soil minerals are positively correlated with $\mathrm{Fe}_{\mathrm{d}}, \mathrm{Al}_{\mathrm{d}}$ and clay $(p<0.05)$. SOM property is positively correlated with SOC content and SOC/N ratio but negatively correlated with SOC-normalized concentrations of WEOC $(p<0.05)$. Hydrolases are positively correlated with $\alpha$-glucosidase, $\beta$-glucosidase, alkaline phosphatase and leucine-aminopeptidase activities $(p<0.05)$. All the variables used for PCA yielded KMO $\geq$ 0.5 and BS $<0.01$, indicating that PCA was appropriate. In all cases, PCA results explained $>54 \%$ of variations in variables.

A priori models for the SEM (Fig. S7) are developed based on knowledge and hypotheses involving three main groups of variables (SOM property, microbial biomass and enzyme activities) that are influenced by past aridity and soil minerals and directly regulate mineralization. Microbial community structures (i.e., F/B and $\mathrm{G}+/ \mathrm{G}-$ ratios) are not included due to their complex relationships with mineralization (Griffiths et al., 
2001; Nannipieri et al., 2003; also see details in Results). The $q \mathrm{CO}_{2}$ is excluded in the model due to its intrinsic strong correlation with mineralization. Microbial biomass and enzyme activities are directly linked to soil minerals (Bontti et al., 2009), SOM property and aridity index, while enzyme activities are also influenced by soil pH (Sinsabaugh et al., 2008; Sinsabaugh, 2010) and microbial producers (PLFAs). Soil pH is affected by aridity index (van Breemen et al., 1984). For the added fresh litter, its mineralization potential is not directly linked to SOM property while all other pathways remain the same (Fig. S7b). Based on a priori models, step-wise exclusion of variables with non-significant regression weight and covariance (estimated by Akaike information criterion scores) was used until a minimal adequate model was achieved. The size of effect on substrate mineralization potentials for environmental variables is reflected by the standardized path coefficients (Milcu et al., 2013). The adequacy of the constructed SEM is indicated by non-significant chi-squared $\left(\chi^{2}\right)$ tests $(p>0.05)$, a low root mean square error of approximation index (RMSEA $<0.05$ ), Tucker-Lewis Index (TLI $\geq 0.90)$ and a high comparative fit index (CFI $\geq 0.95$; Schermelleh-Engel et al., 2003). The SEM is also modified with Satorra-Bentler correction to improve the chisquare approximation of goodness-of-fit test statistics for our relatively small dataset with non-normal distributions and validated with the Bollen-Stine bootstrap test $(p>0.1)$ (Hesterberg et al., 2005; Mancinelli et al., 2013). 
2 Supplementary tables

Table S1. Mineral composition of the studied grassland soils (analyzed by X-ray diffraction).

\begin{tabular}{lccc}
\hline Site & $\begin{array}{c}\text { Quartz } \\
(\%)\end{array}$ & $\begin{array}{c}\text { Feldspar } \\
(\%)\end{array}$ & $\begin{array}{c}\text { Calcite } \\
(\%)\end{array}$ \\
\hline OB & 45.7 & 54.3 & na \\
DQ & 65.4 & 20.7 & 13.9 \\
HLHT & 72.9 & 17.5 & 9.6 \\
XH & 69.8 & 30.2 & na \\
XG & 84.9 & 15.1 & na \\
HB & 55.8 & 33.4 & 10.8 \\
\hline
\end{tabular}


Table S2. The abundance-weighted average $\delta^{13} \mathrm{C}$ of phospholipid fatty acids (PLFAs) in the litter-amended and control soils, litter-derived carbon in PLFAs

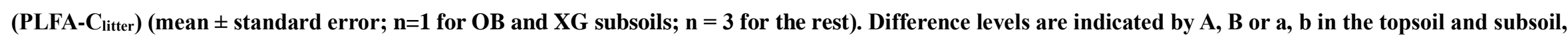
respectively.

\begin{tabular}{lccc}
\hline Site & $\begin{array}{c}\text { Litter-amended soil } \\
\text { PLFA- }{ }^{13} \mathrm{C}(\%)\end{array}$ & $\begin{array}{c}\text { Control soil } \\
\text { PLFA- }{ }^{13} \mathrm{C}(\%)\end{array}$ & PLFA-C $_{\text {litter }}(\%)$ \\
\hline OB & & Topsoil & \\
DQ & $-8.20 \pm 5.21$ & $-26.31 \pm 0.18$ & $1.40 \pm 0.40 \mathrm{~B}$ \\
HLHT & $-2.66 \pm 1.38$ & $-26.18 \pm 0.16$ & $1.82 \pm 0.11 \mathrm{~B}$ \\
XH & $-11.37 \pm 2.00$ & $-25.38 \pm 0.59$ & $2.84 \pm 0.16 \mathrm{~A}$ \\
XG & $-8.21 \pm 5.90$ & $-22.67 \pm 0.35$ & $1.12 \pm 0.46 \mathrm{~B}$ \\
\hline OB & $-0.26 \pm 2.62$ & $-25.47 \pm 0.04$ & $1.95 \pm 0.20 \mathrm{AB}$ \\
DQ & 0.35 & Subsoil & $1.49 \mathrm{a}$ \\
HLHT & $30.74 \pm 13.97$ & -18.80 & $4.31 \pm 1.08 \mathrm{a}$ \\
XH & $7.83 \pm 3.34$ & $-25.05 \pm 0.38$ & $2.53 \pm 0.26 \mathrm{a}$ \\
XG & $1.13 \pm 5.14$ & $-24.95 \pm 1.27$ & $1.99 \pm 0.40 \mathrm{a}$ \\
\hline
\end{tabular}


Table S3. Information on the mineralization potential relative to soil organic carbon (SOC) in published incubation studies.

\begin{tabular}{|c|c|c|c|c|c|c|c|c|}
\hline Reference & Location & Vegetation & $\begin{array}{l}\text { Aridity } \\
\text { index }\end{array}$ & $\begin{array}{l}\text { Soil depth } \\
\quad(\mathrm{cm})\end{array}$ & Soil pH & $\begin{array}{l}\mathrm{SOC} / \\
\mathrm{N}\end{array}$ & $\begin{array}{l}\text { Incubation } \\
\text { time (d) }\end{array}$ & $\begin{array}{r}\text { OMP } \\
(\%)\end{array}$ \\
\hline Čapek, et al. (2015) & Taymir Peninsula, Russia & Tundra & 0.93 & $\mathrm{Oa}$ & 6.2 & 18.7 & 91 & 5.23 \\
\hline Feng and Simpson (2008) & Alberta, Canada & Grassland & 0.45 & $0-16$ & 6.8 & NA & 86 & 7.26 \\
\hline Gillabel, et al. (2010) & Termunck, Belgium & Cropland & 1.10 & $5-15$ & NA & 10.6 & 99 & 4.03 \\
\hline Guenet, et al. (2010) & Versailles, France & Cropland & 0.82 & $5-20$ & 7.2 & 10.8 & 80 & 1.15 \\
\hline Jia, et al. (2017) & $\begin{array}{l}\text { Qinghai-Tibetan } \\
\text { Plateau,China }\end{array}$ & Grassland & 0.69 & $0-10$ & 8.0 & 12.6 & 86 & 5.34 \\
\hline Lü, et al. (2015) & Chenda Town, China & Forest & 1.41 & $0-10$ & NA & NA & 90 & 2.95 \\
\hline Ma, et al. (2013) & Inner Mongolia, China & Grassland & 0.41 & $0-10$ & 6.3 & 11.1 & 100 & 2.89 \\
\hline Schimmelpfennig, et al. (2014) & Linden, Germany & Grassland & 0.90 & $0-15$ & 5.8 & 10.6 & 93 & 3.02 \\
\hline Thomsen, et al. (1999) & Lerbjerg, Denmark & Cropland & 1.47 & NA & NA & NA & 105 & 2.95 \\
\hline Zheng, et al. (2012) & Colorado, America & Grassland & 0.92 & $0-20$ & 9.0 & NA & 93 & 6.41 \\
\hline
\end{tabular}


Table S4. Litter decomposition rate in field litterbag or laboratory decay experiments.

\begin{tabular}{|c|c|c|c|c|}
\hline Reference & Litter type & Location of experiment & $\begin{array}{l}\text { Decomposition time } \\
\text { (d) }\end{array}$ & Litter decay $(\%)$ \\
\hline Davis, et al. (2003) & Tree leaves & Tropical forest & 90 & 40 \\
\hline Guenet, et al. (2010) & Wheat-straw & Laboratory & 80 & 39 \\
\hline \multirow{2}{*}{ Pascault, et al. (2013) } & Alfalfa & \multirow{2}{*}{ Laboratory } & 120 & 28 \\
\hline & Wheat & & 120 & 17 \\
\hline Shaw and Harte (2001) & E. grandiflorum & Subalpine meadow & 46 & 73 \\
\hline \multirow{2}{*}{ Sievers and Cook (2018) } & Hairy vetch & \multirow{2}{*}{ Tropical cropland } & 84 & 96 \\
\hline & Cereal rye & & 84 & 88 \\
\hline \multirow{3}{*}{ Wang, et al. (2014) } & E. speciosus & \multirow{3}{*}{ Temperate cropland } & 90 & 74 \\
\hline & S. viridis & & 90 & 58 \\
\hline & E. indica & & 90 & 60 \\
\hline Yahdjian, et al. (2006) & S. speciosa & Tropical shrubland & 90 & 10 \\
\hline
\end{tabular}


Table S5. Results of Kaise-Meyer-Olkin (KMO) test and Bartlett test of sphericity (BS) for variables used for principle component analysis (PCA) in the paper.

\begin{tabular}{lccc}
\hline Parameter & Variables included & $\begin{array}{l}\text { KMO } \\
\text { value }\end{array}$ & BS test \\
\hline Soil minerals & $\mathrm{Fe}_{\mathrm{d}}(+), \mathrm{Al}_{\mathrm{d}}(+)$, Clay $(+)$ & 0.53 & $\chi^{2}=40 ; p<0.001$ \\
SOM property & $\mathrm{SOC}(+), \mathrm{SOC} / \mathrm{N}(+)$, WEOC $(-)$ & 0.57 & $\chi^{2}=21 ; p<0.001$ \\
Hydrolases (control) & $\mathrm{AG}(+), \mathrm{BG}(+), \mathrm{AP}(+), \mathrm{LAP}(+)$ & 0.50 & $\chi^{2}=93 ; p<0.001$ \\
Hydrolases (litter-amended) & $\mathrm{AG}(+), \mathrm{BG}(+), \mathrm{AP}(+), \mathrm{LAP}(+)$ & 0.61 & $\chi^{2}=99 ; p<0.001$ \\
\hline
\end{tabular}

$\mathrm{Fe}_{\mathrm{d}}$ : dithionite-extractable iron; $\mathrm{Al}_{\mathrm{d}}$ : dithionite-extractable aluminum; SOM: soil organic matter; SOC: soil organic carbon; N: nitrogen; WEOC: water-extractable organic carbon; AG: $\alpha$-glucosidase; BG: $\beta$-glucosidase; AP: alkaline phosphatase; LAP: leucine-aminopeptidase. Soil minerals are positively correlated (indicated by “+”) with Fe ${ }_{\mathrm{d}}$, $\mathrm{Al}_{\mathrm{d}}$ and clay; SOM property is positively correlated with SOC contents and SOC/N ratios but negatively correlated (indicated by “-”) with WEOC concentrations ( $p<0.05$ ). Hydrolases are positively correlated with all tested hydrolytic enzymes $(p<0.05)$. 
Table S6 Detected phospholipid fatty acids (PLFAs) markers used for microbial groups.

\begin{tabular}{ccccc}
\hline $\mathrm{G}+$ & $\mathrm{G}-$ & Fungi & Actinomycetes & non-specific PLFAs \\
\hline$i 15: 0$ & $16: 1 \omega 7 c$ & $18: 2 \omega 6,9 c$ & $10 \mathrm{Me} 16: 0$ & $16: 0$ \\
$a 15: 0$ & $c y 17: 0$ & $18: 1 \omega 9 c$ & $10 \mathrm{Me} 17: 0$ & $17: 0$ \\
$i 16: 0$ & $18: 1 \omega 7 c$ & $10 \mathrm{Me} 18: 0$ & $18: 0$ \\
$i 17: 0$ & $c y 19: 0$ & & $20: 0$ \\
$a 17: 0$ & & & $16: 1 \omega 5$ \\
& & & $16: 1 \omega 11$ \\
\end{tabular}

$\mathrm{G}+$ and $\mathrm{G}$ - refer to Gram-positive and Gram-negative bacteria, respectively. 


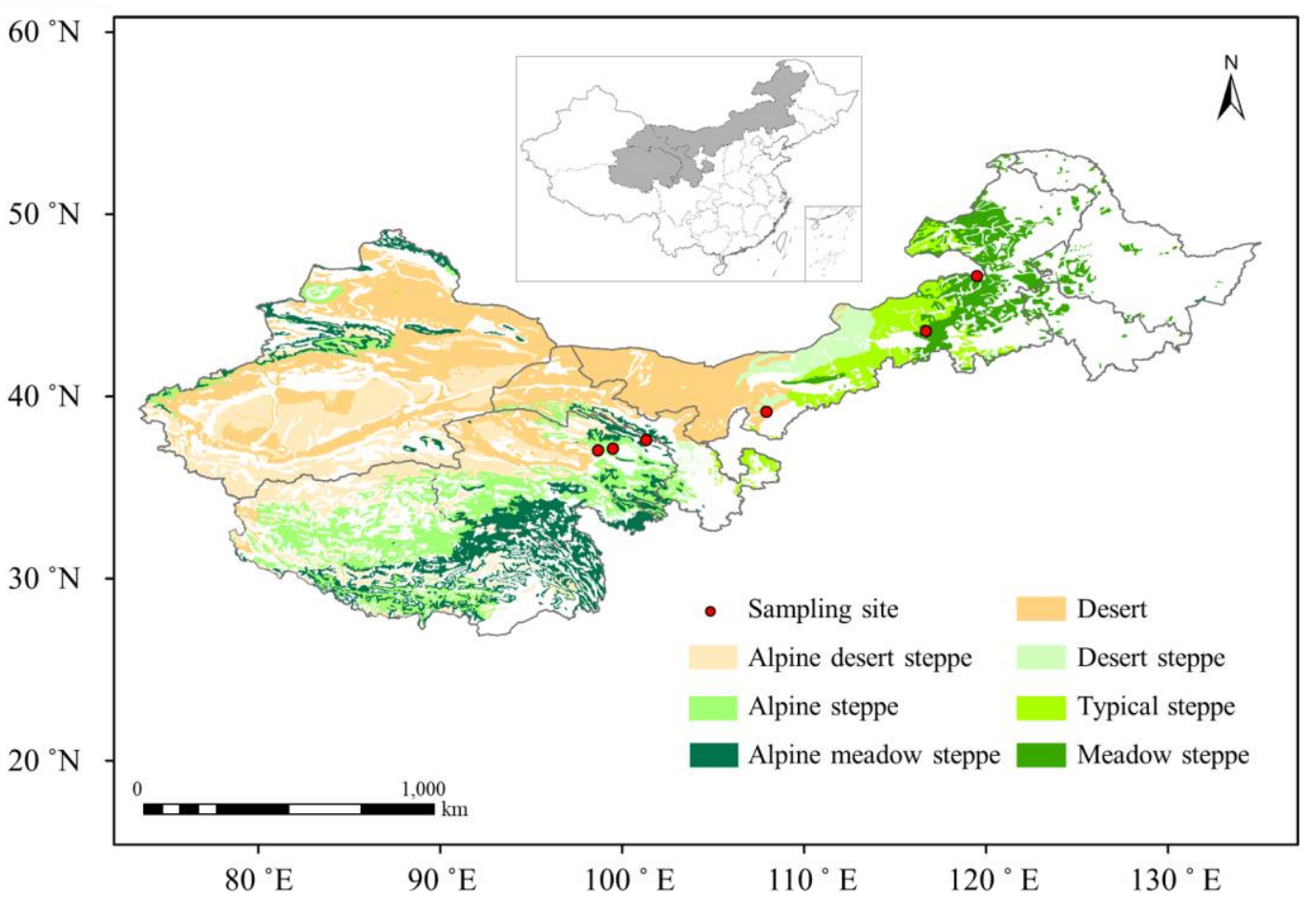

Figure S1. Map of study area and sampling sites. 


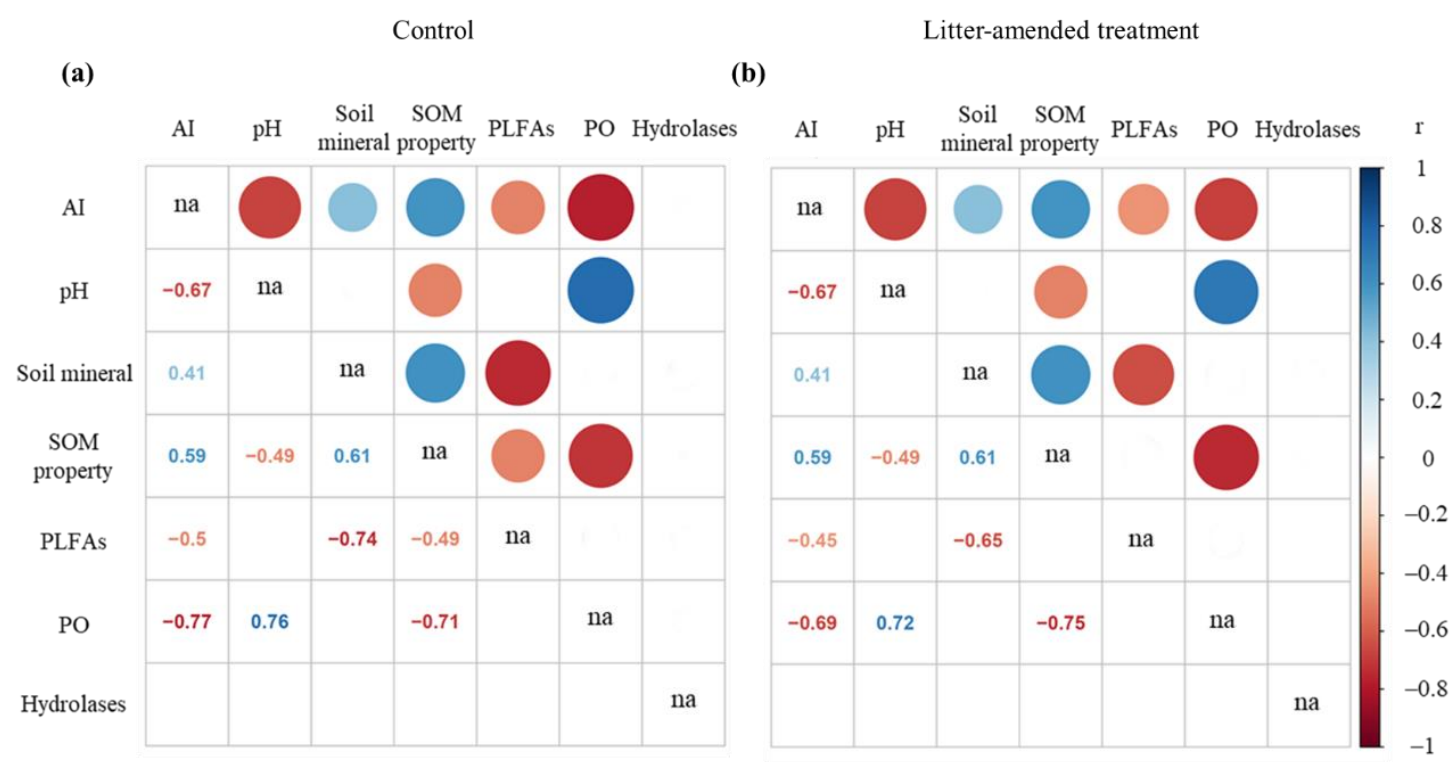

(c)

(d)
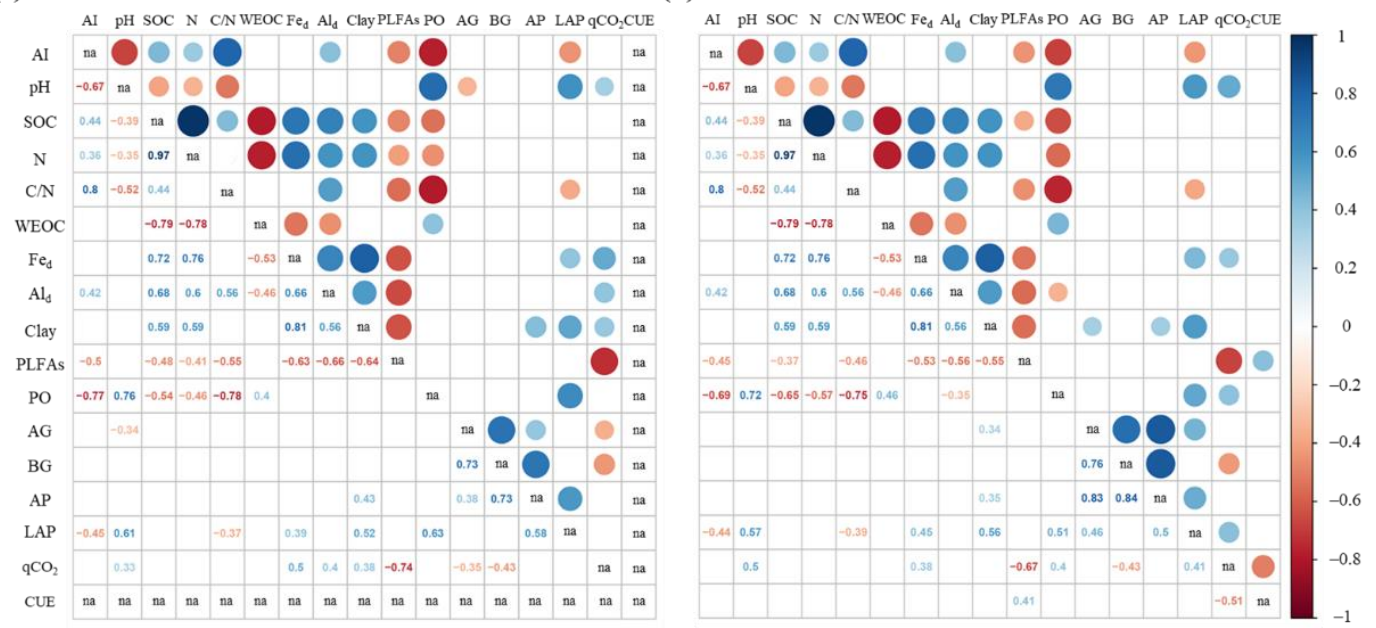

Figure S2. Correlation matrix of environmental variables in the control (a, c) and litter-amended soils (b, d). Numbers in the lower left triangle of the matrix indicate Spearman correlation coefficients (r) between corresponding variables $(p<0.05 ; n=36$, which is proportional to the size of the colored dots in the upper right triangle. Empty cells indicate non-significant correlations $(p>0.05)$. AI: aridity index; SOC: soil organic carbon; N: nitrogen; $\mathrm{C} / \mathrm{N}$ : ratio of $\mathrm{SOC} / \mathrm{N}$; WEOC: water-extractable organic carbon; SOM: soil organic matter; Fed: dithionite-extractable iron; Ald: dithionite-extractable aluminum; PLFAs: phospholipid fatty acids; PO: phenol oxidase; AG: a-glucosidase; BG: $\beta$-glucosidase; AP: alkaline phosphatase; LAP: leucine-aminopeptidase; $q \mathrm{CO}_{2:}$ microbial metabolic quotient; CUE': PLFA-based carbon use efficiency; na: not applicable. Soil minerals, SOM property and hydrolases are defined by a principle component analysis (Table S5). 

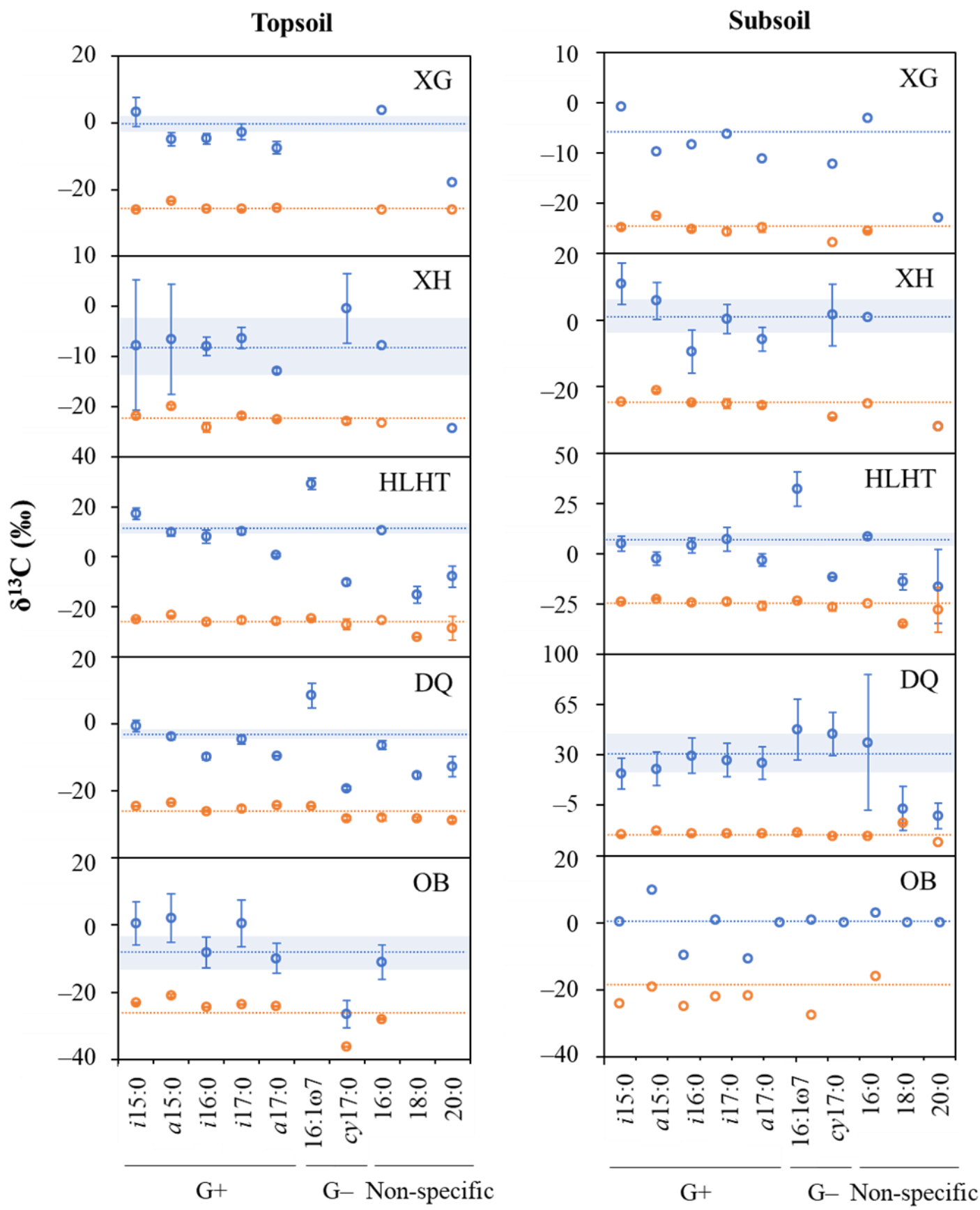

Figure S3. The ${ }^{13} \mathrm{C}$ composition of phospholipid fatty acids (PLFAs) in the control (orange dots) and litter-amended (blue dots) soils at the end of incubation. Mean values are shown with standard error $(n=3)$ except the subsoils of OB and XG (litter-amended only) having only one replicate as low PLFA concentrations prevented accurate ${ }^{13} \mathrm{C}$ measurement. Lines refer to the abundance-weighted average $\delta^{13} \mathrm{C}$ values for the corresponding treatments with shadows representing the associated standard error. Fatty acids are designated according to the standard PLFA nomenclature. G+ and G- refer to Gram-positive and Gram-negative bacteria, respectively. 


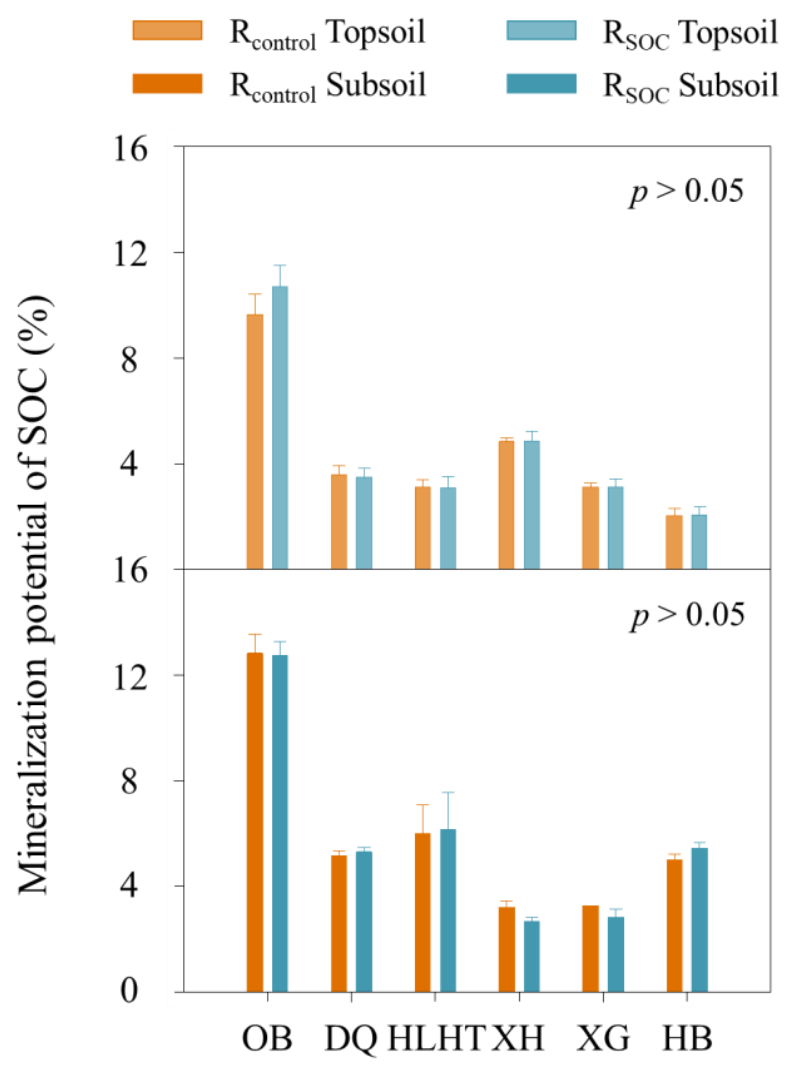

Figure S4. Comparison of mineralization potentials of soil organic carbon (SOC) in the control ( $\left.\mathbf{R}_{\text {control }}\right)$ and leaf-amended treatments (Rsoc). Mean values are shown with standard error $(n=3)$. 


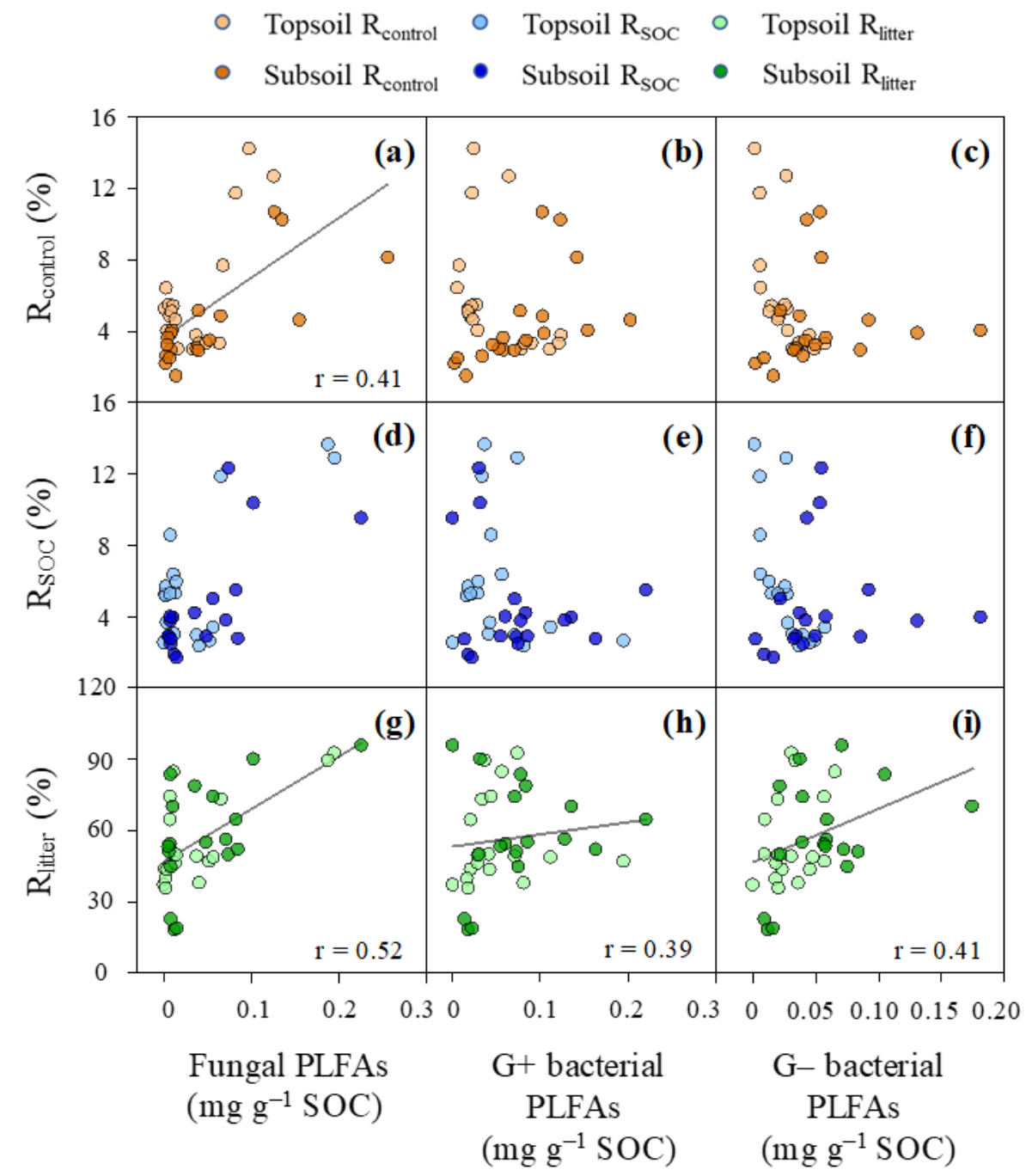

Figure S5. Spearman correlations between the mineralization potential and soil contents of phospholipid fatty acids (PLFAs) for different microbial groups at the end of the 91-day incubation.

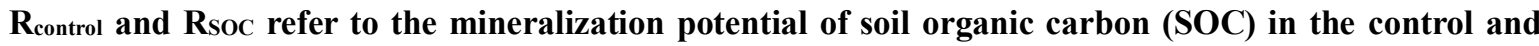
litter-amended treatments, respectively while $R_{\text {litter }}$ refers to the mineralization potential of litter. $\mathbf{G}+$ and $\mathbf{G}$ - refer to Gram-positive and Gram-negative bacteria, respectively. Lines represent significant correlations at a level of $\boldsymbol{p}<\mathbf{0 . 0 5}$. 


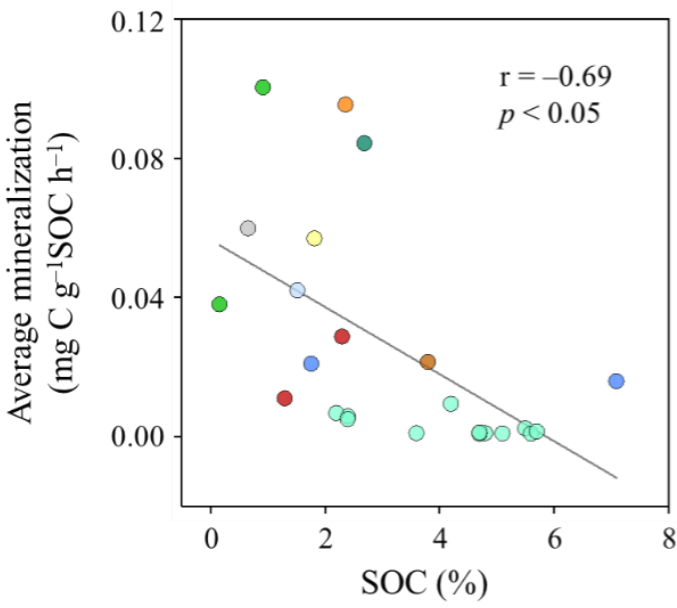

- Brookes, et al. (2008) $\left(25^{\circ} \mathrm{C}, 40 \%\right.$ WHC $)$

- Feng and Simpson $(2008)\left(25^{\circ} \mathrm{C}\right.$, feild capacity $)$

- Gillabel, et al. (2010) $\left(25^{\circ} \mathrm{C}\right.$, feild capacity

- Hawkes, et al. (2017) $\left(24^{\circ} \mathrm{C}, 29 \%\right.$ WHC)

- He, et al. (2013) $\left(25^{\circ} \mathrm{C}, 60 \% \mathrm{WHC}\right)$

- Jia, et al. (2017) $\left(25^{\circ} \mathrm{C}, 65 \% \mathrm{WHC}\right)$

- Lomander, et al. (1998) $\left(25^{\circ} \mathrm{C}, 50 \% \mathrm{WHC}\right)$

- $\mathrm{Lu}$, et al. (2014) $\left(25^{\circ} \mathrm{C}, 80 \%\right.$ water-filled pore space)

- Nie, et al. (2013) $\left(25^{\circ} \mathrm{C}, 60 \% \mathrm{WHC}\right)$

- Wang, et al. (2015) $\left(25^{\circ} \mathrm{C}, 70 \% \mathrm{WHC}\right)$

Figure S6. Spearman correlation between soil mineralization rate and soil organic carbon (SOC) content in published incubation studies at $24-25^{\circ} \mathrm{C}$ with optimal moisture contents. Average mineralization rate is calculated for the first seven days of incubation for experiments of varied duration. 
(a)

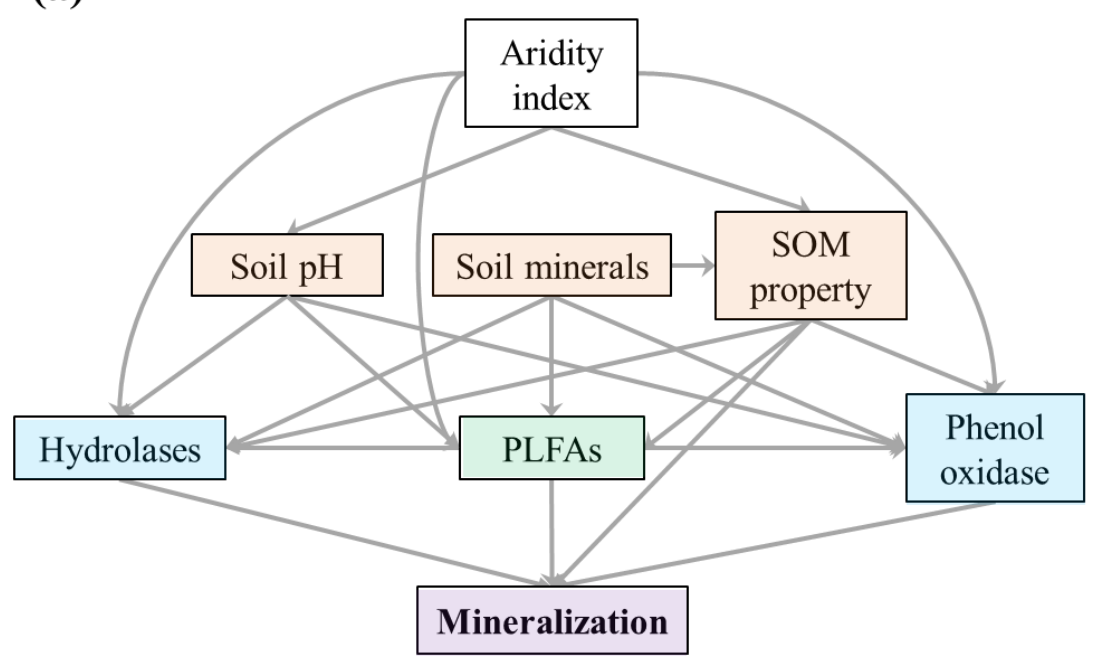

(b)

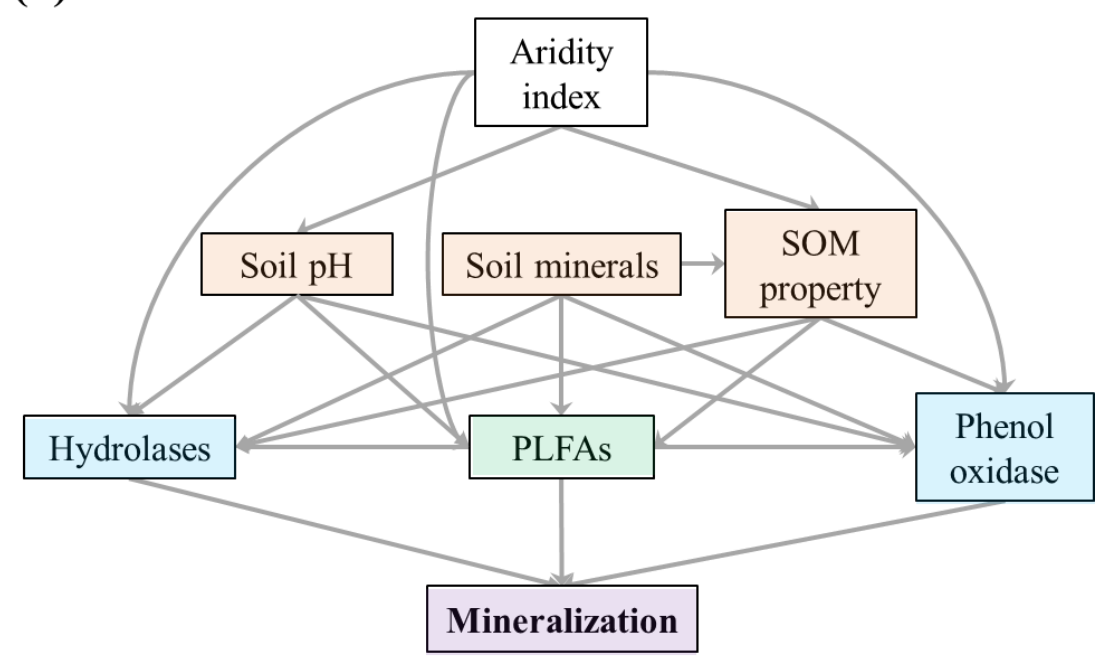

Figure S7. A priori models for the structural equation modeling of substrate mineralization potentials and environmental variables. Arrows indicate flows of causality. Environmental variables are categorized into past climate (i.e., aridity index of sites), extracellular enzymes (in blue) including hydrolyses and phenol oxidase, microbial biomass (in green) represented by phospholipid fatty acids (PLFAs) and soil properties (in orange) including soil pH, soil minerals and soil organic matter (SOM) property. Soil minerals, SOM property and hydrolases are defined by a principle component analysis (Table S5) 


\section{References}

Bligh, E. G. and Dyer, W. J.: A rapid method of total lipid extraction and purification, Can. J. Biochem. Physiol., 37, 911-917, 1959.

Bontti, E. E., Decant, J. P., Munson, S. M., Gathany, M. A., Przeszlowska, A., Haddix, M. L., Owens, S., Burke, I. C., Parton, W. J., and Harmon, M. E.: Litter decomposition in grasslands of Central North America (US Great Plains), Glob. Change Biol., 15, 1356-1363, 2009.

Brookes, P. C., Cayuela, M. L., Contin, M., De Nobili, M., Kemmitt, S. J., and Mondini, C.: The mineralisation of fresh and humified soil organic matter by the soil microbial biomass, Waste Manage., 28, 716-722, 2008.

Čapek, P., Diáková, K., Dickopp, J.-E., Bárta, J., Wild, B., Schnecker, J., Alves, R. J. E., Aiglsdorfer, S., Guggenberger, G., Gentsch, N., Hugelius, G., Lashchinsky, N., Gittel, A., Schleper, C., Mikutta, R., Palmtag, J., Shibistova, O., Urich, T., Richter, A. and Šantrůčková, H.: The effect of warming on the vulnerability of subducted organic carbon in arctic soils, Soil Biol. Biochem., 90, 19-29, 2015.

Davis, S. E., Corronado-Molina, C., Childers, D. L., and Day, J. W.: Temporally dependent C, N, and P dynamics associated with the decay of Rhizophora mangle L. leaf litter in oligotrophic mangrove wetlands of the Southern Everglades, Aquat. Bot., 75, 199-215, 2003.

Denef, K., Roobroeck, D., Manimel Wadu, M. C. W., Lootens, P., and Boeckx, P.: Microbial community composition and rhizodeposit-carbon assimilation in differently managed temperate grassland soils, Soil Biol. Biochem., 41, 144-153, 2009.

Feng, X. and Simpson, M. J.: Temperature responses of individual soil organic matter components, J. Geophys. Res., 113, doi:10.1029/2008JG000743, 2008.

Feng, X. and Simpson, M. J.: Temperature and substrate controls on microbial phospholipid fatty acid composition during incubation of grassland soils contrasting in organic matter quality, Soil Biol. Biochem., 41, 804-812, 2009.

Fry, B.: Stable isotope ecology, Springer Science + Business Media, LLC, Berlin, 2006.

Gillabel, J., Cebrian-Lopez, B., Six, J., and Merckx, R.: Experimental evidence for the attenuating effect of SOM protection on temperature sensitivity of SOM decomposition, Glob. Change Biol., 16, 2789$2798,2010$.

Griffiths, B. S., Ritz, K., Wheatley, R., Kuan, H. L., Boag, B., Christensen, S., Ekelund, F., Sorensen, S. J., Muller, S., and Bloem, J.: An examination of the biodiversity-ecosystem function relationship in arable soil microbial communities, Soil Biol. Biochem., 33, 1713-1722, 2001.

Guckert, J. B., Antworth, C. P., Nichols, P. D., and White, D. C.: Phospholipid, ester-linked fatty acid profiles as reproducible assays for changes in prokaryotic community structure of estuarine sediments, FEMS Microbiol. Lett., 31, 147-158, 1985.

Guenet, B., Neill, C., Bardoux, G., and Abbadie, L.: Is there a linear relationship between priming effect intensity and the amount of organic matter input? Appl. Soil Ecol., 46, 436-442, 2010.

Harwood, J. L. and Russell, N. J.: Lipids in plants and microorganisms, George Allen and Unwin Ltd., London, 1984.

Hawkes, C. V., Waring, B. G., Rocca, J. D., and Kivlin, S. N.: Historical climate controls soil respiration 
responses to current soil moisture, Proc. Natl. Acad. Sci. U. S. A., 114, 6322-6327, 2017.

He, N., Wang, R., Gao, Y., Dai, J., Wen, X., and Yu, G.: Changes in the temperature sensitivity of SOM decomposition with grassland succession: implications for soil C sequestration, Ecol. Evol., 3, 5045$5054,2013$.

Hesterberg, T., Moore, D. S., Monaghan, S., Clipson, A., and Epstein, R.: Bootstrap methods and permutation tests, in: Introduction to the Practice of Statistics, edited by: Moore, D. S. and McCabe, G. P., Freeman Inc., New York, 2005.

Jia, J., Feng, X., He, J.-S., He, H., Lin, L., and Liu, Z.: Comparing microbial carbon sequestration and priming in the subsoil versus topsoil of a Qinghai-Tibetan alpine grassland, Soil Biol. Biochem., 104, $141-151,2017$.

Lomander, A., Katterer, T., and Andren, O.: Carbon dioxide evolution from top- and subsoil as affected by moisture and constant and fluctuating temperature, Soil Biol. Biochem., 30, 2017-2022, 1998.

Lü, M., Xie, J., Wang, C., Guo, J., Wang, M., Liu, X., Chen, Y., Chen, G., and Yang, Y.: Forest conversion stimulated deep soil $\mathrm{C}$ losses and decreased $\mathrm{C}$ recalcitrance through priming effect in subtropical China, Biol. Fert. Soils, 51, 857-867, 2015.

Lu, W., Ding, W., Zhang, J., Li, Y., Luo, J., Bolan, N., and Xie, Z.: Biochar suppressed the decomposition of organic carbon in a cultivated sandy loam soil: A negative priming effect, Soil Biol. Biochem., 76, 12-21, 2014.

Ma, X., Ambus, P., Wang, S., Wang, Y., and Wang, C.: Priming of soil carbon decomposition in two Inner Mongolia grassland soils following sheep dung addition: a study using ${ }^{13} \mathrm{C}$ natural abundance approach, Plos One, 8, e78578, doi:10.1371/journal.pone.0078578, 2013.

Mancinelli, R., Marinari, S., Di Felice, V., Savin, M. C., and Campiglia, E.: Soil property, $\mathrm{CO}_{2}$ emission and aridity index as agroecological indicators to assess the mineralization of cover crop green manure in a Mediterranean environment, Ecol. Indic., 34, 31-40, 2013.

Milcu, A., Allan, E., Roscher, C., Jenkins, T., Meyer, S. T., Flynn, D., Bessler, H., Buscot, F., Engels, C., Gubsch, M., Konig, S., Lipowsky, A., Loranger, J., Renker, C., Scherber, C., Schmid, B., Thebault, E., Wubet, T., Weisser, W. W., Scheu, S., and Eisenhauer, N.: Functionally and phylogenetically diverse plant communities key to soil biota, Ecology, 94, 1878-1885, 2013.

Nannipieri, P., Ascher, J., Ceccherini, M. T., Landi, L., Pietramellara, G., and Renella, G. A.: Microbial diversity and soil functions, Eur. J. Soil Sci., 54, 655-670, 2003.

Nie, M., Pendall, E., Bell, C., Gasch, C. K., Raut, S., Tamang, S., and Wallenstein, M. D.: Positive climate feedbacks of soil microbial communities in a semi-arid grassland, Ecol. Lett., 16, 234-241, 2013.

Pascault, N., Ranjard, L., Kaisermann, A., Bachar, D., Christen, R., Terrat, S., Mathieu, O., Leveque, J., Mougel, C., Henault, C., Lemanceau, P., Pean, M., Boiry, S., Fontaine, S. and Maron, P.-A.: Stimulation of different functional groups of bacteria by various plant residues as a driver of soil priming effect, Ecosystems, 16, 810-822, 2013.

Schermelleh-Engel, K. and Moosbrugger, H.: Evaluating the fit of structural equation models, tests of significance descriptive goodness-of-fit measures, Method. Psychol. Res., 8, 23-74, 2003.

Schimmelpfennig, S., Mueller, C., Gruenhage, L., Koch, C., and Kammann, C.: Biochar, hydrochar and uncarbonized feedstock application to permanent grassland-Effects on greenhouse gas emissions and 
plant growth, Agr. Ecosyst. Environ., 191, 39-52, 2014.

Shaw, M. R. and Harte, J.: Control of litter decomposition in a subalpine meadow-sagebrush steppe ecotone under climate change, Ecol. Appl., 11, 1206-1223, 2001.

Sievers, T. and Cook, R. L.: Aboveground and root decomposition of cereal rye and hairy vetch cover crops, Soil Sci. Soc. Am. J., 82, 147-155, 2018.

Sinsabaugh, R. L.: Phenol oxidase, peroxidase and organic matter dynamics of soil, Soil Biol. Biochem., 42, 391-404, 2010.

Sinsabaugh, R. L., Lauber, C. L., Weintraub, M. N., Ahmed, B., Allison, S. D., Crenshaw, C., Contosta, A. R., Cusack, D., Frey, S., Gallo, M. E., Gartner, T. B., Hobbie, S. E., Holland, K., Keeler, B. L., Powers, J. S., Stursova, M., Takacs-Vesbach, C., Waldrop, M. P., Wallenstein, M. D., Zak, D. R., and Zeglin, L. H.: Stoichiometry of soil enzyme activity at global scale. Ecol. Lett., 11, 1252-1264, 2008.

Thomsen, I. K., Schjønning, P., Jensen, B., and Kristensen, K.: Turnover of organic matter in differently textured soils II. Microbial activity as influenced by soil water regimes, Geoderma, 89, 199-218, 1999.

van Breemen, N., Druscoll, C. T., and Mulder, J.: Acidic deposition and internal proton sources in acidification of soils and waters, Nature, 307, 599-604, 1984.

Wang, G., Zhang, L., Zhang, X., Wang, Y., and Xu, Y.: Chemical and carbon isotopic dynamics of grass organic matter during litter decompositions: A litterbag experiment, Org. Geochem., 69, 106-113, 2014.

Wang, H., Xu, W., Hu, G., Dai, W., Jiang, P., and Bai, E.: The priming effect of soluble carbon inputs in organic and mineral soils from a temperate forest, Oecologia, 178, 1239-1250, 2015.

Yahdjian, L., Sala, O. E., and Austin, A. T.: Differential controls of water input on litter decomposition and nitrogen dynamics in the Patagonian steppe, Ecosystems, 9, 128-141, 2006.

Zheng, J., Stewart, C. E., and Cotrufo, M. F.: Biochar and nitrogen fertilizer alters soil nitrogen dynamics and greenhouse gas fluxes from two temperate soils, J. Environ. Qual., 41, 1361-1370, 2012. 